\author{
原発性副鼻腔霊胞の 4 症例 \\ 伊藤 勇・末野 康平・飯島 正道 \\ 野口 雄五・馬場 道忠

\section{Primary Paranasal Sinus Cysts ; A Report of Four Cases} \\ Isamu Itoh, Kohei Sueno, Masamichi Iijima, \\ Yugo Noguchi and Michitada Baba \\ (Omiya Red Cross Hospital)
}

We rarely encounter primary paranasal sinus cysts in clinical practice. Recently, we treated 2 cases of primary cysts of the frontal and ethmoidal sinuses and 2 cases of anterior ethmoid sinus cysts over a relatively short time span. The cases are presented along with a review of the literature.

For diagnosis, CT examination was very useful. MRI examination is an effective diagnostic tool when the cyst invades the intraorbital or intracranial space or for differentiating cystic mass from tumor.

Surgery is the primary therapeutic modality. Early surgery is highly recommended in patients with complications.

Key words : primary paranasal sinus cyst, CT, MRI, surgical treatment

はじめに

日常臨床においてょくみられる副鼻腔潩胞には術後性 上䋶襄胞があるが，手術や外傷などの副鼻腔疾患の既往 の無い原発性副鼻腔㧼胞に遭遇することは比較的稀であ る.今回，われわれは原発性と考えられる前頭・篩骨洞

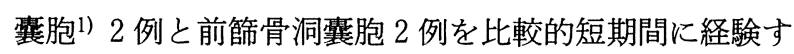
る機会を得たので若干の文献的考察を加えて報告する.

症例 $1: 66$ 歳, 女性.

\section{症例}

主訴 : 左眼袷内側腫瘤.

既往歷，家族歷：特記すべきことなし．

現病歷: 平成 6 年 1 月中旬ごろに左眼窩内側腫瘤に気 ついた. 当院眼科を受診し CT Kて副鼻腔腫瘍を疑われ 平成 6 年 2 月 9 日当科を受診した.

現症: 初診時, 左眼窩内側に $20 \times 25 \mathrm{~mm}$ の骨性に硬
い半球状の腫瘤が触知された (図 1). 眼球突出や流涙は 認めなかった．前鼻鏡検査では左中鼻甲介は浮腫状に腫 脹し中鼻道の狭小を認めた。耳, 咽喉頭に異常を認めず, 頸部その他にリンパ節は触知しなかった。

検查所見 : CT 飞て左前篩骨洞に等濃度で周囲が平滑 な襄胞状陰影を認め, 眼窝篩骨板は一部欠損し囊胞の眼 窩内進展を認めた(図 2 ).

経過：節骨洞翼胞と診断し消炎酵素剂等による保存的 治療を始めたところ, 腫瘤の縮小傾向を認めた. 6 力月 経過した現在腫瘤の増大傾向は認めていない。

症例 $2: 70$ 歳, 女性.

主訴：左鼻根部腫瘤.

既往歷，家族歴：特記すべきことなし。

現病歷: 平成 5 年 11 月頃左鼻根部の腫瘤に気づき当院 皮膚科を受診した。皮膚疾患は否定され副鼻腔疾患を疑 われ平成 5 年 12 月 9 日当科を受診した. 


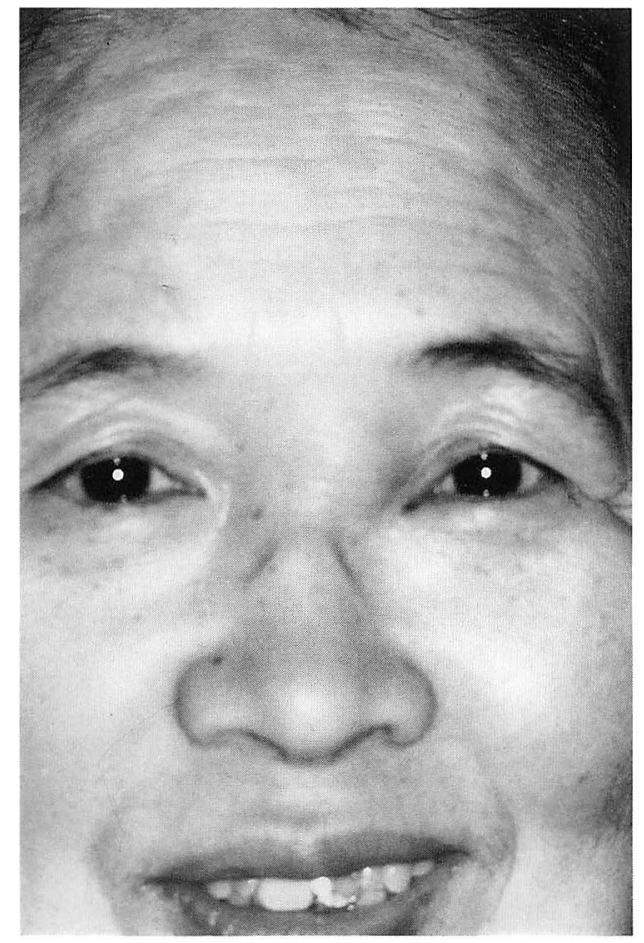

図 1 症例 1 の初診時顔貌. 左眼窩内側に腫瘤を認める.

現症 : 初診時, 左鼻根部に $25 \times 25 \mathrm{~mm}$ の弾性のある 圧痛を伴う腫瘤を認めた(図 3 )。前鼻鏡検査では中鼻甲 介の肥厚を認め, 副鼻腔ファイバースュピーでは鼻前頭 管は膜性に閉鎖していた，複視等の視器症状はなく眼球 運動障害も認めなかった。また, 耳, 咽喉頭に異常を認 めず，頸部その他にリンパ節は触知しなかった。

検查所見：CT では左前節骨洞から前頭洞にかけて等 濃度の囊胞状陰影々前頭洞前壁の骨欠損を認めた(図 $4)$.

経過 : 骨欠損部位より穿刺したところ茶褐色の粘稠な 貯留液が吸引され前頭・篩骨洞弶胞と診断した. 一般検 查にて糖尿病の診断を受けたことなどより手術治療を希 望せず保存的治療で経過を観察していたが，平成 6 年 2 月上旬より左眼の内転障害が出現したため同年 3 月 23 日 局所麻酔下に前頭洞篩骨洞開放術を施行した。手術は Killian 法に準ずる外切開にて前頭洞前壁の骨欠損部よ り囊胞を開放した，次いで鼻内より浮腫状に腫大した中 鼻甲介を形成後, 膜性に閉鎖した鼻前頭管を開放, 拡大 乙鼻前頭管にシリコンチューブを挿入した４４週間留置 した後チューブを鼻腔内より抜去した。術後, 鼻根部腫

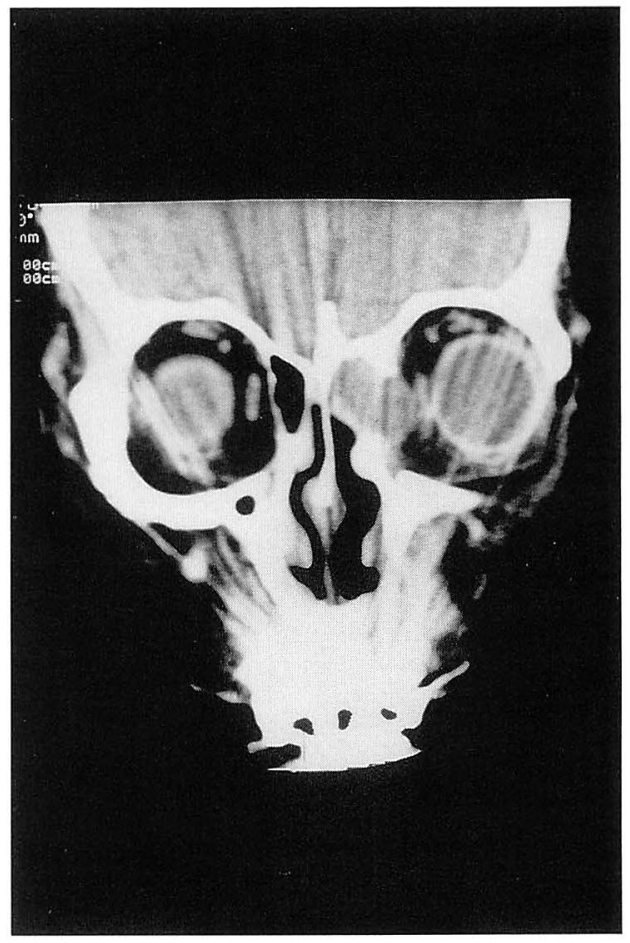

図 2 症例 1 の CT. 左前穊骨洞に眼窩内進展を伴ら等濃度陰 影を認める。

瘤は消失し, 眼球運動障害も改善され (図 5 ), 現在まで 5 カ月間鼻前頭管の閉鎖傾向を認めていない.

症例 $3: 64$ 歳, 女性.

主訴 : 左鼻根部腫瘤.

既往歴, 家族歴 : 特記すべきことなし.

現病歴: 平成 5 年 12 月頃, 左鼻根部の腫瘤に気づき近 医眼科を受診した。視器障害は認めず， CTにて副鼻腔 腫瘍を疑われ平成 6 年 2 月 18 日当科を紹介された.

現症: 初診時, 左鼻根部に母指頭大の骨性に硬い腫瘤 が触知された. 前鼻鏡検查では左中鼻道に半球状の膨隆 を認めた。耳, 咽喉頭に異常を認めず, 頸部その他にり ンパ節は触知しなかった。

検查所見：CT では前篩骨洞に辺縁平滑で, 等濃度囊 胞状陰影を認女, 眼窩節骨板は一部欠損し囊胞の眼窝内 進展がみられた(図6).

経過：前篩骨洞襄胞と診断し 3 月 17 日局所麻酔下に鼻 内篩骨洞開放術を施行した. 左中鼻道に半球状に膨隆し た囊胞前壁を大きく切除すると囊胞は鼻前頭管, 眼窝篩 骨板, 第亚基板の範囲に単房性に存在していた. 鼻前頭 管は著明に拡大されていた。内容は茶褐色の膿性粘液で 


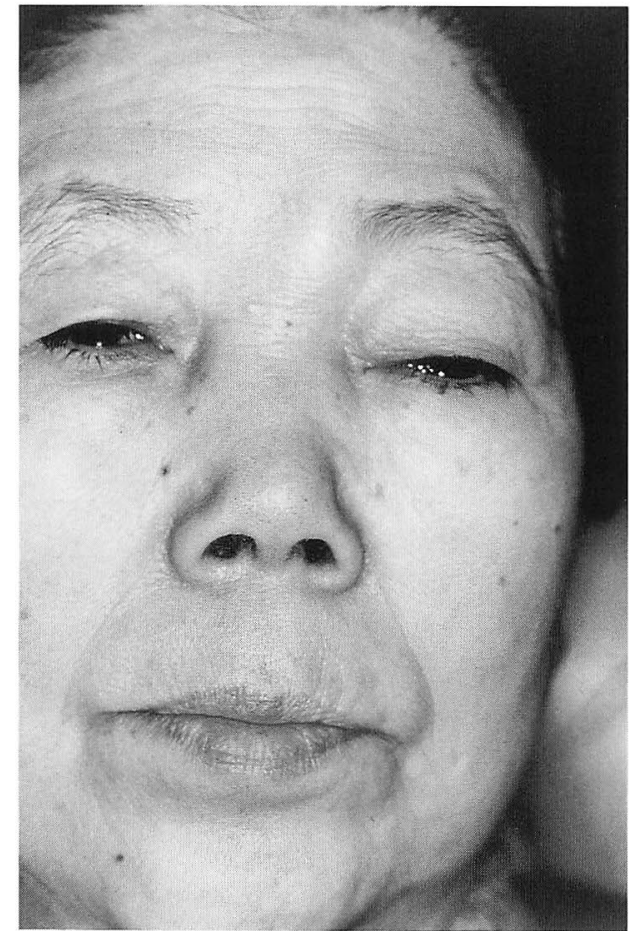

図 3 症例 2 の初診時顔貌. 左鼻根部に腫瘤を認める.

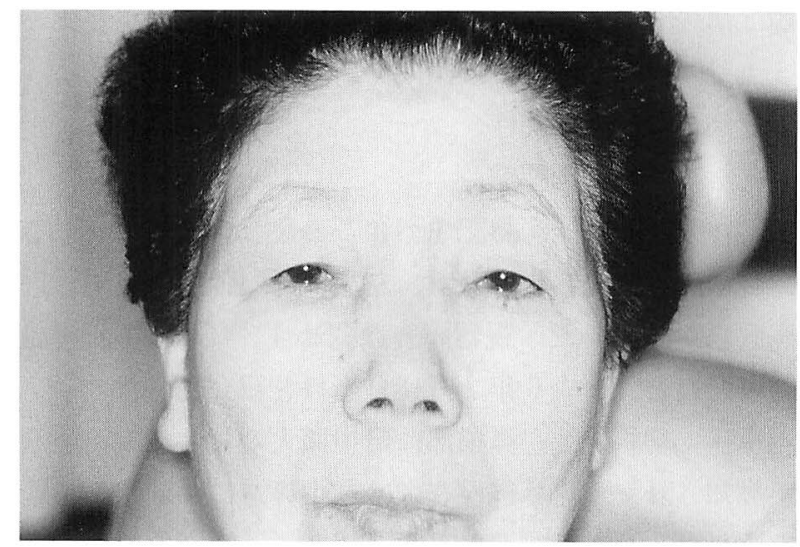

図 5 症例 2 の術後顔貌. 鼻根部腫瘤は消失した。

あった，術後は現在までの 5 カ月間中鼻道の閉鎖傾向は 認めていない。

症例 $4: 77$ 歳, 男性.

主訴: 左眼球突出, 左上眼瞼部腫脹.

既往歴, 家族歴 : 特記すべきことなし。

現病歴: 平成 5 年 11 月頃, 左眼球突出掞上び左上眼瞼

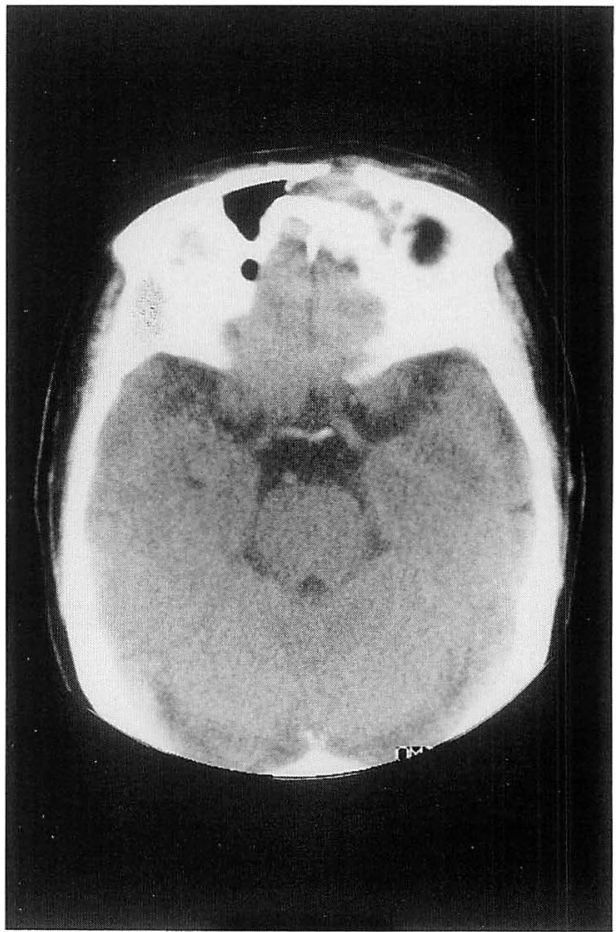

図 4 症例 2 の CT．左前頭洞前壁の骨欠損を伴ら等濃度陰影 を認める。

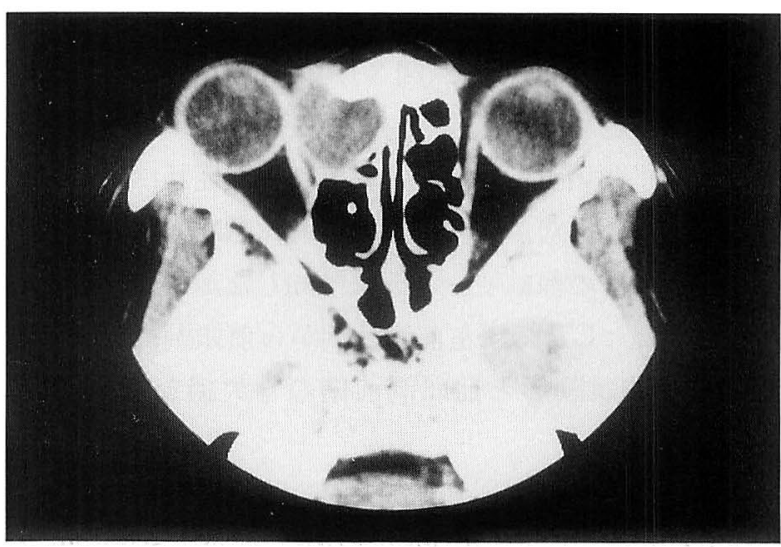

図 6 症例 3 の CT. 左前篩骨洞に等濃度陰影を認める.

部の腫瘤に気づき当院眼科を受診した．CTにて副鼻腔 腫瘍による眼球突出を疑われ平成 5 年 12 月 28 日当科を受 診した。

現症 : 初診時, 左眼球の突出, および下外側偏位と左 上眼瞼部に母指頭大の一部自壊した腫瘤を認めた(図 7 ). 前鼻鏡検査では中鼻甲介の浮腫状腫大以外飞著变 


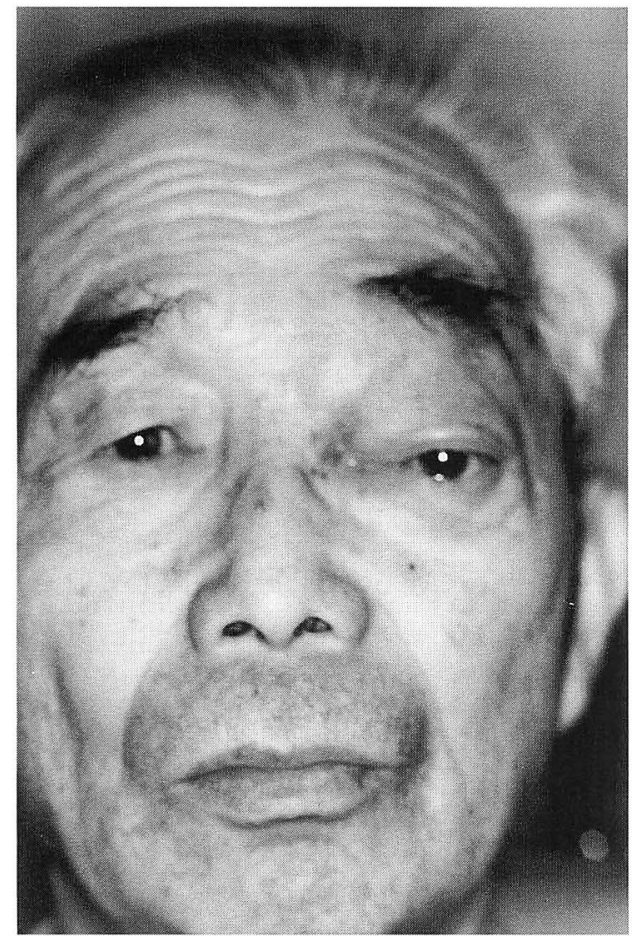

図 7 症例 4 の初診時顔貌. 左眼瞼部に一部自壊した腫瘤と, 左眼球の下外側偏位を認める.

は認めなかった，耳，咽喉頭に異常を認めず，頸部その 他にリンパ節は触知しなかった。

検查所見 : CT では左前頭洞から前節骨洞にわたる等 濃度の囊胞状陰影と，一部前頭洞後壁の骨欠損を認めた。 また両側上顎洞にも副鼻腔炎を疑わせる陰影を認めた (図 8 ). MRI では T1 強調画像にて等信号, T2 強調画 像にて高信号の前頭洞〜篩骨洞にかけての囊胞状病変を 認めた。また，左眼球は下外側一圧排され，前頭葉も後 方へ圧排されていた(図 9 ).

また，術前検査の ECG に異常を認め，循環器科で狭 心症と診断された。

経過：前頭洞篩骨洞囊胞之診断し，平成 6 年 4 月 7 日 局所麻醉下に鼻外法による前頭洞篩骨洞開放術を施行し た．手術は killian 法に準ずる外切開にて前頭洞前壁の 骨欠損部より囊胞を開放し，次いで鼻内より中鼻道を充 分に拡大し膜性に閉鎖した鼻前頭管を開放し，開放した 鼻前頭管にシリコンチューブを留置した。術後は眼球突 出も改善し，現在までの 5 カ月間鼻前頭管の閉鎖傾向を 認めていない。

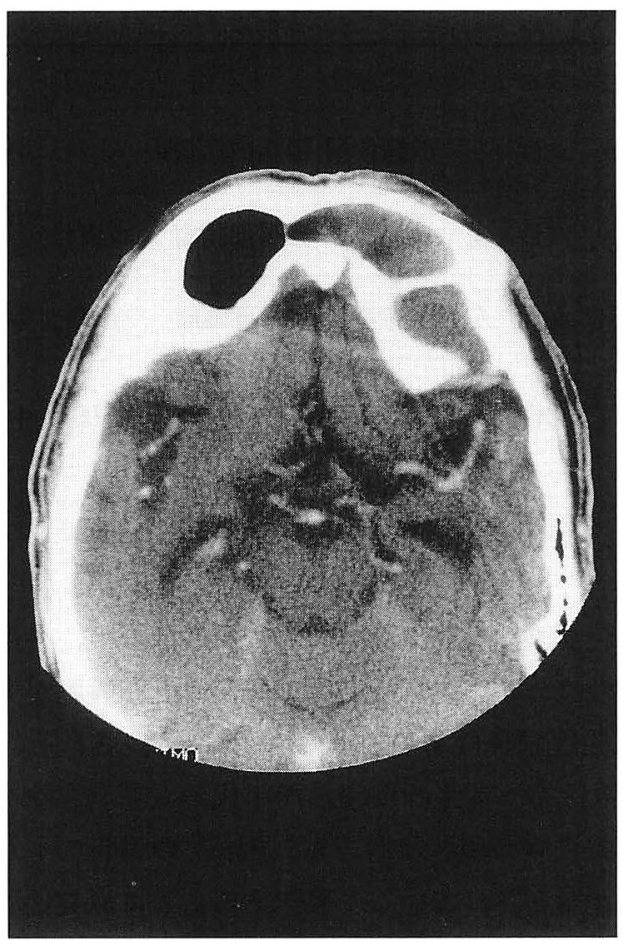

図 8 症例 4 の CT. 左前頭洞に等濃度陰影を認める.

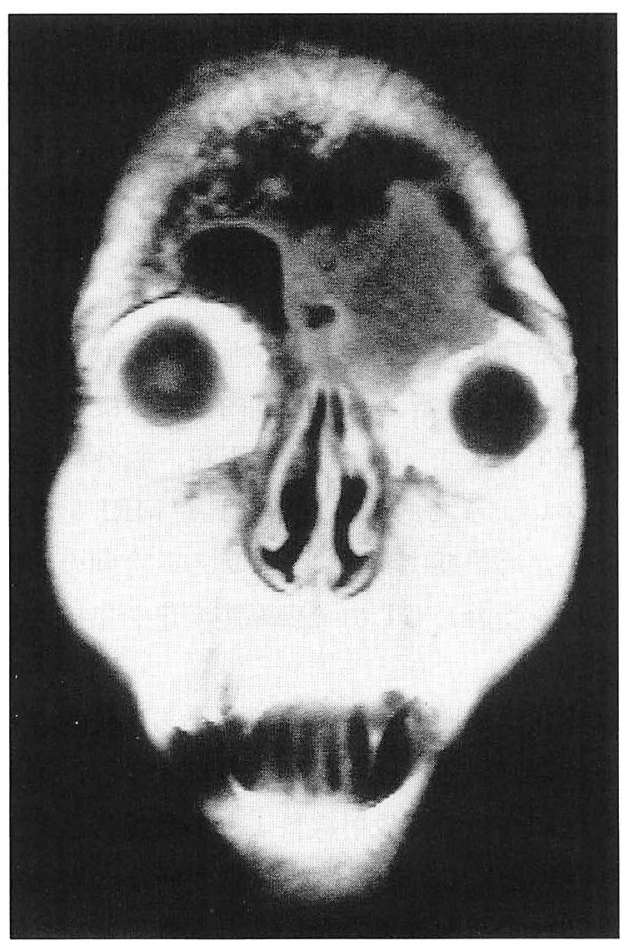

図 9 症例 4 の MRI. T1 強調画像にて左前頭葉, 眼球の圧排 を認める。 
表 1 症例のまとめ.

\begin{tabular}{|c|c|c|c|c|c|c|c|c|c|}
\hline 症例 & 年齢 & 性別 & 患側 & 病変部位 & 主 訴 & 初診科 & 鼻内所見 & CT/MRI 所見 & 治療・合併症 \\
\hline 1 & 66 & 女性 & 左 & 前節骨洞 & 眼窩内側腫脹 & 眼科 & 中鼻甲介の浮腫状腫大 & \begin{tabular}{|l} 
前笁骨洞に䧆胞陰影 \\
眼窩篩骨板の一部損
\end{tabular} & 保存的 \\
\hline 2 & 70 & 女性 & 左 & $\begin{array}{l}\text { 前頭洞 } \\
\text { 節骨洞 }\end{array}$ & 鼻根部腫瘤 & 皮虙科 & \begin{tabular}{|l|} 
中鼻甲介の肥厚 \\
鼻前頭管周囲の膜性閉鎖
\end{tabular} & 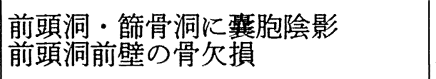 & $\begin{array}{l}\text { 鼻外法+鼻内法 } \\
\text { 糖尿病 }\end{array}$ \\
\hline 3 & 64 & 女性 & 左 & 前穊骨洞 & 鼻根部腫瘤 & 眼科 & 中鼻道上部に半球状隆起 & 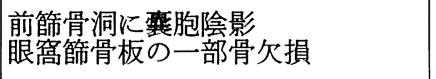 & 鼻内篩骨洞開放術 \\
\hline 4 & 77 & 男性 & 左 & 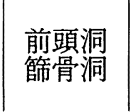 & \begin{tabular}{|l} 
眼瞼部腫瘤 \\
眼球突出
\end{tabular} & 眼科 & 中鼻甲介の浮腫状腫大 & 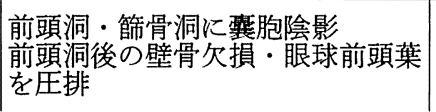 & 鼻外法+鼻内法 \\
\hline
\end{tabular}

\section{考察}

副鼻腔慗胞は一般に発生原因により原発性，外傷性，

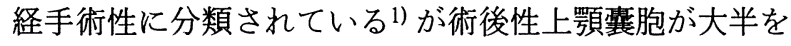
占め原発性副鼻腔囊胞は比較的稀に経験される.大野 ら 2) の報告では本邦の1960～70年代の上顎洞を除く原発 性副鼻腔製胞の頻度は24.7\%, 飯沼 ${ }^{1)}$ の報告でも扣括む ね10～20\%とされている．興味あることに原発性副鼻腔 襄胞は術後性襄胞に比較して女性に多く高齢者に多いと されており3), 我々の症例も 3 例は女性であった(表 1 ). これは副鼻腔手術を受ける機会が男性に多いためである と推察されている4).

原発性副鼻腔輩胞の部位別頻度では前頭洞あるいは前 頭・篩骨洞が最も多く, 鼻前頭管のもつ解剖学的要因に より，閉塞し易いとされている1) 6). 左右差について広

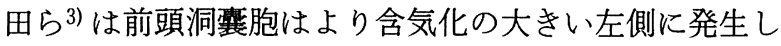
易いと報告して拉り，我々の症例もすべて左側であった (表 1).

症状は炎症症状，圧迫症状，炎症圧迫症状があげられ ているが1)，隣接蔵器である眼窩内あるいはその周辺に 影響を及ぼし易く5)，したがって眼科，脳外科を受診す る場合が多いようである．近年 CTや MRI を施行する 機会が多いため早期に発見されている. 今回の症例でも 3 例は眼科を受診し CT にて副鼻腔疾患を指摘されてい る.

診断は症状，局所所見，画像診断から比較的容易であ るが，試験穿刺あるいは手術により確定する．副鼻腔表 胞の CT 像については放射線科より多数報告されており CT 像の特徵として(1)膨隆性の等濃度病変(2)均一な内容 (3)平滑な辺縁(4)造影効果のないこと(5)骨破壊をともない 易い(6)容の CT 值は脳実質とほぼ等濃度であることな どが報告されている67). 富岡ら ${ }^{6)}$ はCTによる有病正診
率97.1\%と報告している. CT 撮影に際して前頭洞と篩 骨洞は歯牙によるアーチファクトも受けにくく，CT は 診断上非常に有用であった．MRI は眼窩内，頭蓋内に 進展した例や腫瘍との鑑別を要する場合に必要な検査と 考えて扣り，組織内含水量の増加を反映し long SE で腫 瘍よりも高信号を示すとされている8)。治療は手術を原 則とし，特に眼科的合併症を有する症例では早期に手術 が必要であると考えられている9).

$$
\text { まとめ }
$$

1 ）短期間に原発性副鼻腔囊胞の 4 症例を経験した.

2） 3 例は手術，1例は保存的に治療した.

3 ）診断には CT 検査が有用であったことを強調した

\section{参考文献}

1) 飯沼壽考 : 副鼻腔襄胞概論. JOHNS 5 : 661 668, 1989.

2 ）大野誠一, 大野郁夫, 山本 誠, 他 : 副鼻腔嚷胞の臨床的 問題点について.耳鼻 $25: 738 \sim 745,1979$.

3 ）広田佳治, 清水弥生, 大澤博之, 他 : 前頭洞襄胞の臨床的 研究. 日耳鼻 $89: 731 \sim 743,1986$.

4) 栫 博幸, 青山 敬, 喜多村健, 他 : 副鼻腔㖶胞手術の臨 床統計. 耳鼻臨床 補59:43～52, 1992.

5 ）森本賢治, 榎本和子, 小林一豊, 他 : 眼窩合併症を伴った 副鼻腔襄胞 -9 年間の観察一. 耳鼾 $31: 466 \sim 470,1985$.

6 ）富岡邦昭, 小林可奈子, 天沼 誠, 他 : 副鼻腔粘液整腫34 例の検討. 臨放 $33: 1067 \sim 1070,1988$.

7 ) Hesselink JR : Evaluation of mucoceles of the paranasal sinusses with computed tomography. J Comput Assist Tomogr $5: 122 \sim 125,1981$.

8 ）野口由美, 加藤 勤, 河相 吉, 他 : 副鼻腔粘液輫胞 膿襄胞の MRI一．臨放 $34: 1389 \sim 1395,1989$.

9 ）高木 茂, 二宮俊一郎：上類洞ピオチェーレの 2 症例. 耳 鼻 $20: 631 \sim 635,1974$.

$$
\left(\begin{array}{l}
\text { 別刷請求先 : 伊藤 勇 } \\
\text { T173 東京都板橋区大谷口上町 } 30-1 \\
\text { 日本大学医学部耳鼻咽喉科学教室 }
\end{array}\right)
$$

